\section{IJ§ER}

ISSN: 2149-5939
International Journal of Social Sciences and Education Research

Online, http://dergipark.gov.tr/ijsser

Volume: 3(2), 2017

\title{
Ağızdan ağıza pazarlama iletişiminin, fitness merkezi kullanıcılarının besin destek ürünü satınalma karar sürecine etkisi
}

\author{
The effect of Word of Mouth (WOM) communication on the fitness center \\ participants' decision making process about nutritional supplements purchase
}

\author{
Suzan Dal1 $\quad$ S. Bora Çavuşoğlu² Özlem Karaman³
}

\begin{abstract}
Received Date: $01 / 09$ / $2016 \quad$ Accepted Date: 15/ $01 / 2017$
$\ddot{\boldsymbol{O}} z$

Bu çalışmanın amacı İstanbul ili Avrupa yakasında faaliyet gösteren spor salonlarından yararlanarak spor yapan kişilerin besin destek ürünü satınalma karar sürecinde ă̆ızdan ă̆ıza pazarlama iletişimin etkisini araştırmaktır. Belirlenen amaç doğrultusunda, Istanbul ili Avrupa yakasında faaliyet gösteren fitness merkezi ve spor salonlarından tesadüfi olarak seçilen, 16-51 yaş aralığında olan ve yaş ortalaması 28 olan, toplam 138 kişi çalışmaya katılmıştır. Çalışmada Didem AYDIN tarafindan geçerlilik ve güvenilirlik analizler yapılmış olan ölçek kullanılmıştır. Çalışmada kullanılan anket formu toplam 30 soru olmak üzere üç kısımdan oluşmuş 5 'li Likert tipi ölçekle değerlendirilmesi istenmiştir. Çalışmaya ait veriler SPSS 20 programı ile sınanmıştır. Çalışmada Frekans, çapraz tablo, $t$-testi, anova analizleri kullanılmış. Çalışmamızda çıkan bulgular arasında besin destek ürünü alırken erkeklerin \% 83'ü kadınların ise \% 79 'unun tecrübe, bilgi tavsiye ve görüşleri dikkate aldiğı gözlemlenmiştir. Kattlımclların tecrübe, bilgi tavsiye ve görüşler dikkate alarak \%34.8 protein tozu \%10.9 amino asit, \%8.7 le-karnitin veya cla ürünleri ni tercih etmekte. Çalıșmamıza katılanlar internet üzerinden besin destek ürünü satın alırken kullandıkları kanal bakımından erkekler sırası ile ilk olarak sohbet ve forum sitelerini, alışveriş sitelerini ve haber sitelerini kullanırken kadınlar sohbet ve forum sitelerini, video paylaşım sitelerini ve alışveriş sitelerini kullandıklarl gözlemlenmiştir.
\end{abstract}

Anahtar sözcükler: Ăğzdan ă̆ıza iletişsim, besin destek ürünü. satın alma karar süreci

\begin{abstract}
This study aims to understand effects of word of mouth communication on Europe side of Istanbul sport centers participants decision making process about nutritional supplements purchase. The participants of survey choosen randomly are between the range of 16-51 and their average of age is 28 . Totally 138 persons were participated to study. Didem AYDIN made validity and reliability test and survey form includes 30 questions and three parts. Five unit Likert scale is used. The data were tested by SPSS 20. Frequency, crosstab, t-test-anova analysis were used. We observed that when they are purchasing nutritional supplements, \%83 of men and \% 79 of women are considering experience, information, and advices. The participants considered experience, information, and advices and they preferred \% 34.8 protein powder, \% 10.9 amino asit, \% 8.7 carnitine or cla products. Men participants are purchasing products via internet and they use respectively chat and forum websites, shopping websites and news websites. Women participants are purchasing products via internet and they use respectively chat and forum websites, video share websites and shopping websites. When participants of study are making purchase decision, \% 46.4 of them care expertness of source, \%29.7 of them care consultants experience, \% 15.2 of them care consultants information. We observed that men consider experience, information and advice more than women at their nutrition supplement purchasing process. Also it can be said that the sources experience, information and expertness has a significant role at consumers purchasing decisions.
\end{abstract}

Keywords: Word of Mouth communication, nutrition supplement production, purchasing decision process

\footnotetext{
${ }^{1}$ Okutman, İstanbul Üniversitesi, Spor Yöneticiliği Bölümü, suzann.dal@gmail.com

${ }^{2}$ Yrd.Doç.Dr., İstanbul Üniversitesi, Spor Yöneticiliği Bölümü,boracavusoğlu@windowslive.com

${ }^{3}$ Doktora Öğrencisi, İstanbul Üniversitesi, Sağlık Bilimleri Enstitüsü, Spor Yönetim Bilimleri A.B.D., karaman@istanbul.edu.tr
} 
Dal, S., Çavuşoğlu, S.B., Karaman, Ö. (2017). The effect of Word of Mouth (WOM) communication on the fitness center participants' decision making process about nutritional supplements purchase. International Journal of Social Sciences and Education Research, 3(2), 456-466.

\section{Giriş}

\subsection{Illetişim ve ă̆ızdan ăğza pazarlama iletişimi}

İletişim, toplumdan topluma ve zamana göre değişen yol ve yöntemleri kullanarak duygu ve düşüncelerin bireyler ve gruplar arasında aktarımıdır. Yaşam içerisinde iletişime herkesin ihtiyacı vardır çünkü iletişim, insanların birbirini anlamaları için gerekli olan bir köprü konumundadır. İnsanlar ister tek başına, ister toplumla birlikte yaşasın, iletişim kurarak amaçlarına ulaşırlar. İnsanda iletişim kurma ihtiyacı, çevreyi etkileme isteğinden kaynaklanır. İletişim, insanın kendini bir insan olarak gerçekleştirmesi ve sosyal süreçlere girmesi bakımından da önemlidir. Günümüzde iletişimin öneminin artmasının bir diğer nedeni ise iletişimin bugün bir güç kaynağı olan bilgi iletiminin temel aracı olmasıdır (Geçikli Vd.,2011,s.165).

Bilgiye bulaşma ihtiyacı ve bunun tüketici tarafından nasıl tatmin edildiği pazarlama araştırmalarının üzerinde önemle durduğu konulardandır. Yüz yüze iletişim türlerinden olan ağızdan ağıza pazarlama iletişimi de günümüzde kabul gören ve müşterilerin tüketim kararlarını şekillendiren bir bilgi alışveriş yöntemidir. Ağızdan ağıza iletişim; ürün veya hizmet sağlayıcılar, işletmeden bağımsız uzmanlar, aile üyeleri ve arkadaşlar gibi gruplar arsında olumlu veya olumsuz sözel iletişim şeklidir (Ennew vd., 2000, s.75).

Tüketiciler, algılanan riski azaltma, güvenilir bilgi kaynağı bulma ve satın alma kararını kolaylaştırmak için ağızdan ağıza iletişime yönelmektedirler. Odabaşı ve Barış, (2003, s.270)'a göre; tüketicilerin başkalarının önerilerine yönelmesinin ve bunlara uymasının iki ana koşulu vardır. Bunlar; (1)Tüketicilerin danışarak elde ettiği kazançların büyüklüğü arttıkça, tüketiciler tavsiyelere daha çok uyum göstermektedirler.(2) Tüketicilerin danışarak elde ettiği kazançların sık olması durumunda, tüketiciler daha çok ilişki kurma eğiliminde olmaktadırlar. Fakat kazanç her zaman satın almanın gerçekleşmesi sonucunu doğurmaz. Tecrübe ve tavsiyeler sonucu tüketicinin elde ettiği bilgi, tüketicinin ürünü satın almaktan vazgeçmesine de sebep olabilir. Burada gerçekleşen fenomen negatif ağızdan ağıza iletişimdir.

\subsection{Spor yapanlarda besin destek ürünü kullanımı}

Besin destek ürünleri sektörü son yıllarda çok hızlı bir büyüme ivmesi kaydetmiş̧ir. İnsanlar sportif müsabakalarda yer almaya başladığından beri, beslenmenin fiziksel performansın tamamlayıcısı olduğunun farkına varılmıştır. Son birkaç on yılda insan metabolizmasını ve egzersiz fizyolojisini anlamakta kat edilen gelişim, besin alımının manipülasyonun spor performansını pozitif yönde etkileyecek potansiyele sahip olduğunu açı bir şekilde göstermiştir. Bunun bir sonucu olarak da egzersiz yapan bireyler üzerinde belirli etkileri olan ürünlerin sayısında artış görülmüştür. (Alpar F.,2011, s.12)

Doğal beslenme destekleri birçok insanın günlük yaşantısını yoğun temposu içinde yetersiz kalan gıda ihtiyacını karşılamaya yönelik ürünlerdir. Kaynağını bilimsel ve hayvansal hammaddelerin oluşturduğu beslenme destekleri, vitamin, mineral, bitkisel içerikli ürünler, sporcu destekleri ve doğal kozmetikli ürünlerdir. (Alkibay S., Kılıçlar A., 2002, s.1)

Argan M. ve Köse H. (2009, s.153), bu ürünlere yönelik alg1, düşünce ve tutumlar ürünün kullanımı üzerinde büyük öneme sahip olduğunu belirtmektedir. Farklı düzeylerde fitness ya da spor salonu niteliğindeki yerlerde spor yapan kişiler bu ürünlere yönelik sahip oldukları tutumlara 
Dal, S., Çavuşoğlu, S.B., Karaman, Ö. (2017). Ağızdan ağıza pazarlama iletişiminin, fitness merkezi kullanıcılarının besin destek ürünü satınalma karar sürecine etkisi. International Journal of Social Sciences and Education Research, 3(2), 456-466.

dayalı olarak davranış eğilimi gösterirler. Diğer bir ifadeyle ürün kullanımı, kullanılan ürün kategorileri, kullanım sıklığı ve bu tür ürünlere yönelik bilgilerin edinimi davranışları ön plana çıkarabilmektedir.

1.3. Spor yapanların besin destek ürünü satın alma kararı vermesinde ă̆ızdan ăğıa iletişsimin etkisi

Çoğu işletme, tüketici-tüketici etkileşimini incelemenin önemini, günümüz tüketicisinin etkileşimli değer yaratma sürecinde eşit olduğu gerçeğiyle ilişkilendirir; çünkü bir işletme yalnızca bir değer teklifi sunabilir ve bu teklifi algılayan ve bu değerin kapsamını belirleyen tüketicidir. Günümüz tüketicileri iyi bilgilendirilmiş ve eğitimlidirler ve satın alma kararlarını agresif pazarlamaya değil, daha çok etkileşimli ilişkilere girdikleri diğer tüketicilerden edindikleri bağımsız bilgilere dayandırırlar. (Grubor A. Vd. 2015, s.131) Diğer tüketicilerle etkileşime geçen spor tüketicisi de satın alma sürecinde hakim konuma gelir ve bundan sonra gelişen tutum ve davranışları spor ürün ve hizmetinin pazarlanmasının etkinliğini belirler.

Spor ürünleri pazarında önemli bir yer kaplayan besin destekleri sadece elit sporcular tarafından kullanılmamakta, gündelik hayat içinde rekreasyonel amaçlı spor yapan kişiler de bu ürünleri kullanmaktadırlar. Spor yapanlar, satın alma kararı verirken spor bu ürünleri kullanmanın gerekliliğini bir yandan sorgularken diğer yandan imaj kaygısı yaşamaktadırlar. Çünkü spor imaj1, yarışma, mücadele, güç, dayanıklılık ve sağlıklı olma gibi çağrışımları güçlendirmektedir. Dolayısıyla reklamlarda kullanılan bu tür benzer imajlar satın almaya daha çok yakınlaştırmaktadır. (Sunay H., Balc1 V.,2003,110)

Araştırmamıza konu olan besin destek ürünlerinin tüketiminde de ağızdan ağıza iletişim etkilidir. Spor yapanlar ürünlere yönelik bilgi birikimi oluştururken başkalarının geçmiş tecrübelerini önemsemekte, denenmiş ürüne ilişkin bilgiye sahip olmayı istemekte ve satın alma kararını bunun sonucunda elde ettikleri birikime göre vermektedirler. Çalışmamızda da bu ürünlerin kullanımında ağızdan ağıza pazarlama iletişiminin etkisi yaş, cinsiyet, ürün çeşidi, iletişim kanalı ve diğer çeşitli faktörler açısından incelenmiştir.

\section{Materyal ve metod}

Araştırmanın evrenini İstanbul'da bulunan fitness merkezi üyeleri oluşturmaktadır. Örneklem belirlemede ise basit tesadüfî örneklem tekniginden yararlanılmıstır. Araştırma örneklemini ise İstanbul ili Avrupa yakasında bulunan, tesadüfü olarak tespit edilmiş fitness merkezi üyeleri oluşturmaktadır. Toplam 5 ayrı fitness merkezine dağıtılan 200 anketten 138'i tam olarak doldurulup değerlendirmeye alınmıştır. 138 katılımcıdan 48 'i kadın 90 erkektir.

Araştırmada veri toplama yöntemi olarak anket kullanılmıştır. Anket formunda yer alan soruların geçerlilik güvenilirlik analizleri Didem Aydın tarafından (2009) yapılmıştır. Kullanılan an- 
Dal, S., Çavuşoğlu, S.B., Karaman, Ö. (2017). The effect of Word of Mouth (WOM) communication on the fitness center participants' decision making process about nutritional supplements purchase. International Journal of Social Sciences and Education Research, 3(2), 456-466.

ket formu toplam 30 soru ve üç kısımdan oluşmuş, 5'li Likert tipi ölçekle değerlendirilmesi istenmiştir. Veriler SPSS 20 programı ile sınanmış, frekans, çapraz tablo, t-testi, anova analizleri kullanılmıştır.

\section{Bulgular}

Tablo 1. Katılımcıların kişisel bilgilerine ait yüzde ve frekans değerleri

\begin{tabular}{|l|l|c|c|}
\hline & & $\mathbf{F}$ & $\mathbf{\%}$ \\
\hline \multirow{4}{*}{ Cinsiyet } & Kadın & 48 & 34,8 \\
\cline { 2 - 4 } & Erkek & 90 & 65,2 \\
\cline { 2 - 4 } & Toplam & 138 & 100,0 \\
\hline \multirow{4}{*}{ Medeni hal } & Bekar & 107 & 77,5 \\
\cline { 2 - 4 } & Evli & 31 & 22,5 \\
\cline { 2 - 4 } & Toplam & 138 & 100,0 \\
\hline \multirow{5}{*}{ Eğitim düzeyi } & İş̧i & 12 & 8,7 \\
\cline { 2 - 4 } & Memur & 10 & 7,2 \\
\cline { 2 - 4 } & Öğrenci & 55 & 39,9 \\
\cline { 2 - 4 } & Esnaf & 6 & 4,3 \\
\cline { 2 - 4 } & Serbest Meslek & 21 & 15,2 \\
\cline { 2 - 4 } & Diğer & 34 & 24,6 \\
\cline { 2 - 4 } & Toplam & 138 & 100,0 \\
\cline { 2 - 4 } & İlk Okul & 1 &, 7 \\
\cline { 2 - 4 } & Orta Okul & 1 &, 7 \\
\cline { 2 - 4 } & Lise & 20 & 14,5 \\
\cline { 2 - 4 } & Üniversite & 101 & 73,2 \\
\cline { 2 - 4 } & Yüksek Lisans Doktora & 15 & 10,9 \\
\cline { 2 - 4 } & Toplam & 138 & 100,0 \\
\hline
\end{tabular}

Tablo 1 incelendiğinde, katılımcıların 90'nının $(\%$ 65,2) erkek, 48'inın (\%34,8) kadın, 107' sinin $(\% 77,5)$ bekar, 31'inin (\% 22,5) evli olduğu görülmektedir. Katılımcıların meslek grubu incelendiğinde ise 12 ' sinin (\% 8,7) işçi, 10'unun (\%7,2) memur, 55'nin (\% 39,9) öğrenci, 6'sının (\% 4,3)esnaf, 21 'inin (\% 15,2) serbest meslek, 34'ünün (\% 4,6) ise diğer meslek grupları ile ilgili çalıştığı görülmektedir. Eğitim düzeylerine baktığımızda ise 1 er $(\%, 7)$ kişinin ilkokul ve ortaokul mezunu olduğu, 20' sinin (\% 14,5) lise mezunu, 101'inin (\% 73,2) üniversite mezunu, 15 'inin $(\% 10,9)$ yüksek lisans, doktora mezunu olduğu gözlemlenmiştir.

Tablo 2. Katılımcıların tavsiye ile ürün alıp alamama durumları

\begin{tabular}{|l|c|c|}
\hline & F & \% \\
\hline Evet & 113 & 81,9 \\
\hline Hayır & 25 & 18,1 \\
\hline Toplam & 138 & 100,0 \\
\hline
\end{tabular}

Tablo 2'de katılımcıların 113 'ünün $(\% 81,9)$ tavsiye ile ürün aldığ1, 25'inin $(\% 18,1)$ ise tavsiye ile ürün almadığı sonucu görülmektedir.

Tablo 3. Katılımcıların deneyimlerini başkaları ile paylaşma durumları

\begin{tabular}{|l|c|c|}
\hline & F & $\mathbf{\%}$ \\
\hline Evet & 126 & 91,3 \\
\hline Hayır & 12 & 8,7 \\
\hline Toplam & 138 & 100,0 \\
\hline
\end{tabular}


Dal, S., Çavuşoğlu, S.B., Karaman, Ö. (2017). Ağızdan ağıza pazarlama iletişiminin, fitness merkezi kullanıcılarının besin destek ürünü satınalma karar sürecine etkisi. International Journal of Social Sciences and Education Research, 3(2), 456-466.

Tablo 3'te katılımcıların 126'sının (\%91,3) deneyimlerini başkaları ile paylaştıkları, 12' sinin $(\% 8,7)$ ise deneyimlerini başkaları ile paylaşmadığı sonucuna ulaşılmıştır.

Tablo 4 . Katılımcıların besin destek ürünü alırken tavsiye alınan kişi ile yakınlık derecesi

\begin{tabular}{|l|l|l|}
\hline & F & $\%$ \\
\hline Aile Bireyi & 16 & 14,2 \\
\hline Arkadaş & 86 & 76,1 \\
\hline İlk Kez Tanıştı̆ım Kişi & 8 & 7,1 \\
\hline Ünlüler & 3 & 2,7 \\
\hline Toplam & 113 & 100,0 \\
\hline
\end{tabular}

Tablo 4'te besin destek ürünü almadan önce tavsiye alınan kişi ile yakınlık derecesine bakı1dığında; katılımcıların 16'sının(\%14,2) aile bireyleri, 86'sının (\%76,1) arkadaş, 8'inin $(\% 7,1)$ ilk kez tanıştığı kişi ile 3'ünün ise (\% 2,7) ise ünlülerin tavsiyesi ile ürün kararını belirlediği gözlemlenmiştir.

Tablo 5. Katılımcıların en son almış olduğu besin destek ürünü

\begin{tabular}{|l|c|c|}
\hline & F & \% \\
\hline Protein Tozu & 48 & 42,5 \\
\hline Amino Asit & 15 & 13,3 \\
\hline Karbonhidrat & 7 & 6,2 \\
\hline Kilo Ve Hacim Kontrol Ürünü & 10 & 8,8 \\
\hline Le-Karnitin Veya Cla Ürünleri & 12 & 10,6 \\
\hline Performans Ve Güç Ürünleri & 6 & 5,3 \\
\hline Kreatin Ürünleri & 5 & 4,4 \\
\hline Sporcu Vitaminleri & 7 & 6,2 \\
\hline Diğer & 3 & 2,7 \\
\hline Toplam & 113 & 100,0 \\
\hline
\end{tabular}

Tablo 5'te katılımcıların en son aldığı besin destek ürününün ne olduğu sorusuna 48'inin $(\% 42,5)$ protein tozu, 15 'inin $(\% 13,3)$ amino asit, 7 'sinin $(\% 6,2)$ karbonhidrat, 10'unun $(\% 8,8)$ kilo ve hacim kontrol ürünü, 12'sinin $(\% 10,6)$ Le-Karnitin Veya Cla Ürünleri, 6'sının $(\% 5,3)$ performans ve güç ürünleri, 5 'inin $(\%$ 4,4) Kreatin Ürünleri, 7'sinin $(\%$ 6,2) sporcu vitaminleri, 3 'ünün $(\% 2,7)$ ise diğer besin destek ürünleri olarak cevap verdiği izlenebilir.

Tablo 6. İnternet aracılığı ile besin destek ürünü alıp almama durumları

\begin{tabular}{|l|l|l|}
\hline & F & $\%$ \\
\hline Evet & 71 & 50,7 \\
\hline Hayır & 67 & 49,3 \\
\hline Toplam & 138 & 100,0 \\
\hline
\end{tabular}


Dal, S., Çavuşoğlu, S.B., Karaman, Ö. (2017). The effect of Word of Mouth (WOM) communication on the fitness center participants' decision making process about nutritional supplements purchase. International Journal of Social Sciences and Education Research, 3(2), 456-466.

Tablo 6'da katılımcıların "İnternet aracılığı ile besin destek ürünü alıyor musunuz?" sorununa 71 'inin (\%50,7) evet, 67'sinin (5 49,3) ise hayır dediği görülebilir.

Tablo 7. İnternetten besin destek ürünü alırken tercih edilen siteler

\begin{tabular}{|l|c|c|}
\hline & F & $\mathbf{\%}$ \\
\hline Alışveriş Siteleri & 15 & 21,1 \\
\hline Sohbet Ve Forum Siteleri & 24 & 33,8 \\
\hline Video Paylaşım Siteleri & 10 & 14,1 \\
\hline Haber Siteleri & 7 & 9,9 \\
\hline Şikayet Siteleri & 9 & 12,7 \\
\hline Sosyal Medya & 6 & 8,5 \\
\hline Toplam & 71 & 100,0 \\
\hline
\end{tabular}

Tablo 7'de katılımciların internetten besin destek ürünü alırken tercih edilen sitelere baktığ1mıda; 15'inin (\% 21,1) alışveriş siteleri, 24'ünün (\% 33,8) sohbet ve forum siteleri, 10'unun (\% 14,1) video paylaşım siteleri, 7'sinin (\% 9,9) haber siteleri, 9'unun (\% 12,7) şikayet siteleri, 6 'sının $(\% 8,5)$ ise sosyal medyayı tercih ettiği görülür.

Tablo 8. Besin destek ürünü Satın alama kararını en çok etkileyen unsurlar

\begin{tabular}{|l|c|c|}
\hline & F & $\mathbf{\%}$ \\
\hline Tv Reklamı & 12 & 8,7 \\
\hline Tavsiye Bilgi Görüş Alma & 92 & 66,7 \\
\hline Promosyon & 11 & 8,0 \\
\hline İnternet & 11 & 8,0 \\
\hline Diğer & 12 & 8,7 \\
\hline Toplam & 138 & 100,0 \\
\hline
\end{tabular}

Tablo 8'de katılımcıların besin destek ürünü satın alama kararını en çok etkileyen unsurlara baktığımızda; 12'sinin (\% 8,7)Tv Reklamı, 92'sinin (\% 66,7) Tavsiye Bilgi Görüş Alma, 11 'inin $(\% 8,0)$ Promosyon, 11 'inin $(\% 8,0)$ internet, 12 'sinin $(\% 8,7)$ ise diğer unsurlardan etkilenerek besin destek ürünü aldıklarını gözlemlenebilir.

Tablo 9. Besin destek ürünü alırken tavsiye alınan kişinin dikkat edilen özelliği

\begin{tabular}{|l|c|c|}
\hline & F & \% \\
\hline Uzmanlığ1 & 64 & 46,4 \\
\hline Bilgisi & 21 & 15,2 \\
\hline Deneyimi & 41 & 29,7 \\
\hline Aldığım Risk & 12 & 8,7 \\
\hline Toplam & 138 & 100,0 \\
\hline
\end{tabular}


Dal, S., Çavuşoğlu, S.B., Karaman, Ö. (2017). Ağızdan ağıza pazarlama iletişiminin, fitness merkezi kullanıcılarının besin destek ürünü satınalma karar sürecine etkisi. International Journal of Social Sciences and Education Research, 3(2), 456-466.

Tablo 9'da katılımcıların besin destek ürünü alırken tavsiye alınan kişinin 64'ünün (\% 46,4) kişinin uzmanlığına, 21'inin (\% 15,2) bilgisine, 41'inin (\% 29,7) deneyimine, 12'sinin ise (\% $8,7)$ aldığı riski göz önünde bulundurduğunu izleyebiliriz.

Tablo. 10 İnternetten besin destek ürünü alırken tercih edilen sitelerin cinsiyete faktörüne göre değişimi

\begin{tabular}{|l|c|c|c|}
\hline & Kadın & Erkek & Toplam \\
\hline Alışveriş Sitesi & 4 & 11 & 15 \\
\hline Sohbet Ve Forum Siteleri & 7 & 17 & 24 \\
\hline Video Paylaşım Siteleri & 5 & 5 & 10 \\
\hline Haber Siteleri & 1 & 6 & 7 \\
\hline Şikayet Siteleri & 4 & 5 & 9 \\
\hline Sosyal Medya & 2 & 4 & 6 \\
\hline Toplam & 23 & 48 & 71 \\
\hline
\end{tabular}

Tablo 10'da katılımciların internetten besin destek ürünü alırken tercih edilen sitelerin cinsiyete faktörüne göre farklılıklarına baktığımızda; 4 kadın 11 erkeğin alışveriş sitelerini, 7 kadının 17 erkeğin sohbet ve forum sitelerini, 5 kadının 5 erkeğin video paylaşım sitelerini, 1 kadın 6 erkeğin haber sitelerini, 4 kadın 5 erkeğin şikayet sitelerini, 2 kadın ve 4 erkeğin ise sosyal medyayı kullandığı bulgularına ulaşılmıştır.

Tablo. 11 Katılımcıların kullandıkları besin destek ürünlerini satın almayı tercih ettikleri internet siteleri

\begin{tabular}{|l|c|c|c|c|c|c|c|}
\hline & $\begin{array}{l}\text { Alışveriş } \\
\text { Siteleri }\end{array}$ & $\begin{array}{l}\text { Sohbet, } \\
\text { Forum } \\
\text { Siteleri }\end{array}$ & $\begin{array}{l}\text { Video } \\
\text { Paylaşım } \\
\text { Siteleri }\end{array}$ & $\begin{array}{l}\text { Haber } \\
\text { Siteleri }\end{array}$ & $\begin{array}{l}\text { Sikayet } \\
\text { Siteleri }\end{array}$ & $\begin{array}{l}\text { Sosyal } \\
\text { Medya }\end{array}$ & Toplam \\
\hline Protein Tozu & 6 & 11 & 3 & 3 & 1 & 3 & 27 \\
\hline Amino Asit & 5 & 3 & 4 & 0 & 0 & 0 & 12 \\
\hline Karbonhidrat & 1 & 1 & 1 & 2 & 0 & 0 & 5 \\
\hline $\begin{array}{l}\text { Kilo Ve Hacim Kontrol } \\
\text { Ürünü }\end{array}$ & 0 & 1 & 0 & 1 & 1 & 2 & 5 \\
\hline $\begin{array}{l}\text { Le-Karnitin Veya Cla } \\
\text { Ürünleri }\end{array}$ & 0 & 3 & 1 & 1 & 1 & 1 & 7 \\
\hline $\begin{array}{l}\text { Performans Ve Güç } \\
\text { Ürünleri }\end{array}$ & 0 & 2 & 1 & 0 & 0 & 0 & 3 \\
\hline Kreatin Ürünleri & 2 & 0 & 0 & 0 & 2 & 0 & 4 \\
\hline Sporcu Vitaminleri & 1 & 0 & 0 & 0 & 0 & 0 & 1 \\
\hline Diğer & 0 & 2 & 0 & 0 & 1 & 0 & 3 \\
\hline Toplam & 15 & 23 & 10 & 7 & 6 & 6 & 67 \\
\hline
\end{tabular}

Tablo 11' de katılımcıların kullandıkları besin destek ürünlerini satın almayı tercih ettikleri internet sitelerine baktığımızda; en çok kullanılan besin destek ürünü olan protein tozunu 11 kişi sohbet ve forum sitelerinden, 6 kişi alışveriş sitelerinden, 3 'er kişi video paylaşım siteleri, haber siteleri, sosyal medyadan, 1 kişi ise şikayet sitesini kullandığını belirtmiştir. Amino asitleri almak 
Dal, S., Çavuşoğlu, S.B., Karaman, Ö. (2017). The effect of Word of Mouth (WOM) communication on the fitness center participants' decision making process about nutritional supplements purchase. International Journal of Social Sciences and Education Research, 3(2), 456-466.

için kullanılan sitelere baktığımızda katılımcılardan 5'i alışveriş sitesi, 4'ü video paylaşım siteleri, 3’ü ise video paylaşım sitelerini kullanmaktadır.

Tablo 12. Katılımcıların aldıkları besin destek ürünü ve eğitim seviyeleri

\begin{tabular}{|l|c|c|c|c|c|c|}
\hline & İlkokul & Ortaokul & Lise & Üniversite & Lisansüstü & Toplam \\
\hline Protein Tozu & 0 & 1 & 6 & 38 & 3 & 48 \\
\hline Amino Asit & 1 & 0 & 5 & 8 & 1 & 15 \\
\hline Karbonhidrat & 0 & 0 & 0 & 7 & 0 & 7 \\
\hline $\begin{array}{l}\text { Kilo Ve Hacim Kontrol } \\
\text { Ürünü }\end{array}$ & 0 & 0 & 1 & 9 & 0 & 10 \\
\hline $\begin{array}{l}\text { Le-Karnitin Veya Cla } \\
\text { Ürünleri }\end{array}$ & 0 & 0 & 2 & 6 & 4 & 12 \\
\hline $\begin{array}{l}\text { Performans Ve Güç } \\
\text { Ürünleri }\end{array}$ & 0 & 0 & 0 & 4 & 2 & 6 \\
\hline Kreatin Ürünleri & 0 & 0 & 0 & 5 & 0 & 5 \\
\hline Sporcu Vitaminleri & 0 & 0 & 0 & 5 & 2 & 7 \\
\hline Diğer & 0 & 0 & 2 & 1 & 0 & 3 \\
\hline Toplam & 1 & 1 & 16 & 83 & 12 & 113 \\
\hline
\end{tabular}

Tablo 12'de Katılımcıların satın aldıkları besin destek ürünü ve eğitim seviyelerine baktığ1mızda; protein tozu kullanan üniversite mezunu 38 , amino asit 8 , karbonhidrat 7 , kilo ve hacim kontrol ürünü 9, le-karnitin veya cla ürünleri 6 , performans ve güç ürünleri 4, kreatin ürünleri 5, sporcu vitaminleri 5 kişi olduğu gözlemlenmiştir. Yüksek lisans ve doktora mezunlarına baktığımızda 3'ünün protein tozu, 1'inin amino asit, 4'ünün le-karnitin veya cla ürünleri, 2'sinin performans ve güç ürünleri ve sporcu vitaminleri kullandığı gözlemlenmiştir. Lise mezunlarına baktığımızda 6'sının protein tozu, 5'inin amino asit 2'sinin le-karnitin veya cla ürünleri kullandığ sonucuna ulaş1lmıştır.

Tablo 13. Katılımcıların eğitim durumu ve internetten ürün alırken tercih ettikleri siteler

\begin{tabular}{|l|l|l|l|l|l|l|}
\hline & \multicolumn{2}{|l}{ Eğitim durumu } \\
\hline & İlkokul & Ortaokul & lise & üniversite & Lisansüstü & \multirow{2}{*}{ Toplam } \\
& & & & & & \\
\hline Alı̧̧veriş Siteleri & 0 & 0 & 3 & 12 & 0 & 15 \\
\hline Sohbet Ve Forum Siteleri & 1 & 0 & 4 & 15 & 4 & 24 \\
\hline Video Paylaşım Siteleri & 0 & 0 & 3 & 7 & 0 & 10 \\
\hline Haber Siteleri & 0 & 1 & 0 & 6 & 0 & 7 \\
\hline Şikayet Siteleri & 0 & 0 & 1 & 5 & 3 & 9 \\
\hline Sosyal Medya & 0 & 0 & 1 & 5 & 0 & 6 \\
\hline Toplam & 1 & 1 & 12 & 50 & 7 & 71 \\
\hline
\end{tabular}

Tablo 13'te katılımcıların eğitim durumu ve internetten ürün alırken tercih ettikleri sitelere baktığımızda; üniversite mezunlarından 15'inin sohbet ve forum sitelerini, 12'si alışveriş sitelerini, 7'si video paylaşım sitelerini, 6'sı haber sitelerini, 5' $\mathrm{i}$ ise şikayet sitelerini ve yine 5'i ise sosyal medyayı kullanmakta olduğu sonucuna ulaşılmıştır. Lisansüstü mezunlarından 4'ü sohbet ve forum sitelerini, 3'ü ise şikayet sitelerini kullanmakta, lise mezunlarından ise 3'ü alışveriş 
Dal, S., Çavuşoğlu, S.B., Karaman, Ö. (2017). Ağızdan ağıza pazarlama iletişiminin, fitness merkezi kullanıcılarının besin destek ürünü satınalma karar sürecine etkisi. International Journal of Social Sciences and Education Research, 3(2), 456-466.

sitesini, 4'ü sohbet ve forum sitesini, 1'i sosyal medyayı, 1'i ise şikayet sitelerini kullanmaktadırlar. İlkokul mezunu 1 kişi sohbet ve forum sitelerini kullandığını belirtirken, ortaokul mezunu olan bir kişi ise haber sitelerini kullandığını belirtmiştir.

\section{Tartışma ve sonuç}

Ağızdan ağıza iletişim yolu ile besin destek ürünü kullanan katılımcılar üzerinde yapmış olduğumuz çalışmada bulguların değerlendirilmesinde elde edilen sonuçlara göre; katılımcıların büyük bir çoğunluğu ( $\% 81$ ) tavsiye ile besin destek ürünü kullanmaktadırlar. Katılımcıların tavsiye aldıkları kişi ile yakınlık derecesine baktığımızda yüksek oranda(\%86), arkadaşlarından tavsiye aldıkları sonucuna varılmıştır. Katılımcıların başkaları ile $(\% 91,3)$ deneyimlerini paylaştıkları gözlemlenmiştir.

Katılımcılar “en son aldığınız besin destek ürünü hangisidir?" sorusuna ağırlıklı olarak sırası ile $(\% 42,5)$ protein tozu, $(\% 13)$ amino asit ve $(\% 10)$ le-karnitin veya cla ürünlerini söylemişlerdir. Katılımcıların yaklaşık yarısı (\% 50,7) internet deneyimi ile ürün aldıklarını belirtmişlerdir. İnternetten besin destek ürünü alırken tercih ettikleri sitelerin sırası ile sohbet ve forum siteleri(\% 33), alışveriş siteleri (\% 21) ve video paylaşım siteleri ( \% 14) olduğu sonucuna varılmıştır. Katılımcıların satın alma kararını en çok etkileyen unsurlar arasında tavsiye bilgi görüş alma (\% $66,7)$ sonucu çıkmıştır. Katılımcıların ağızdan ağıza iletişim yöntemi ile besin destek ürünü alırken tavsiye alınan kişinin en çok uzmanlığını (\% 46) dikkate aldığı belirlenmiştir.

İnternetten besin destek ürünü alırken tercih edilen sitelerin cinsiyete göre farklılıklarına baktığımızda istatistiksel açıdan anlamlı farklılıklar çıkmamıştır. Bununla birlikte, erkek katılımcıların internetten besin destek ürünü almak için sohbet forum sitelerini ve sonrasında haber sitelerini, kadın katılımcıların ise sohbet ve forum sitelerini ve video paylaşım sitelerini tercih ettikleri sonucu çıkmıştır. Katılımcıların kullandıkları besin destek ürünlerini satın almayı tercih ettikleri internet sitelerine baktığımızda; alışveriş ve sohbet, forum sitelerinden protein tozu alınırken, video paylaşım sitelerinden amino asit satın almayı tercih ettikleri sonucuna varılmıştır.

Ağızdan ağıza iletişim yoluyla besin destek ürünü alan fitness merkezi kullanıcılarının büyük çoğunluğunun üniversite mezunu olduğu, ve bunların tercih ettiği besin destek ürününün ise protein tozu olduğu sonuçlarda çıkmıştır. Katılımcıların Eğitim durumu ve internetten ürün alırken tercih ettikleri sitelere baktığımızda üniversite ve lise mezunlarının sohbet ve forum sitelerini sonrasında ise alışveriş sitelerini tercih ettikleri sonucuna ulaşılmıştır.

Halsted (2003) yapmış olduğu çalışma sonucunda; insanların besin destek ürünlerini satın alma kararı sürecinde ağızdan ağıza pazarlama, reklam ve internet ortamındaki bilgilerden önemli ölçüde etkilendiklerini tespit etmiştir. Ergen ve Bekoğlu'nun (2016) çalışması ise, Türkiye'de ağızdan ağıza iletişimin diğer şekilleri olan TV programları, uzman tavsiyeleri ve gazetelerdeki sağlık köşelerindeki bilgilerin insanların satın alma kararını önemli derecede etkilediği sonucunu ortaya koymaktadır.

\section{Kaynakça}

Alkibay, S., Kılıçlar, A. (2002). "Doğal Beslenme Desteklerine İç Pazarın Oluşturulması Üzerine Bir Araştırma”. Ticaret ve Turizm Eğitim Fakültesi Dergisi, Sayı:2, s.79-102.,

Alpar F. (2011). "Vücut Geliştirme Sporcularında Beslenme, Fiziksel Aktivite Ve Besin Takviyesi Kullanım Durumlarının İncelenmesi”. Yayınlanmamış yüksek lisans tezi, Hacettepe Üniversitesi Sağllk Bilimleri Enstitüsü. 
Dal, S., Çavuşoğlu, S.B., Karaman, Ö. (2017). The effect of Word of Mouth (WOM) communication on the fitness center participants' decision making process about nutritional supplements purchase. International Journal of Social Sciences and Education Research, 3(2), 456-466.

Argan M., Köse H. (2009). "Sporcu Besin Desteklerine (Sports Supplements) Yönelik Tutum Faktörleri: Fitness Merkezi Katılımcıları Üzerine Bir Araştırma”. Spor Bilimleri Dergisi Hacettepe 20 (4), 152164

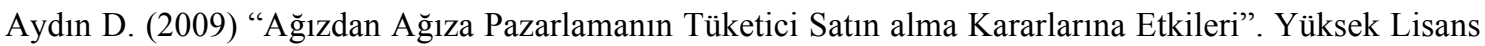
Tezi. Ege Üniversitesi Sosyal Bilimler Enstitüsü

Ergen A. Bekoğlu B.F. (2016), “Türkiye’de Besin Destek Ürünlerine Yönelik Görüşler Ve Tüketici Profilini Tanımlamaya Yönelik Bir Araştırma”. Işsletme Araştırmaları Dergisi, 8/1 s.323-341

Ennew CT, Banerjee AK, Li D. (2000). "Managing Word of Mouth Comminication: Emprical Evidence from India”. International Journal of Bank Marketing, Vol.: 18, Issue: 2, pp.75-83.

Geçikli F., Serçeoğlu N., Üst Ç. (2011). “Örgüt içi İletişim Ve İletişim Tatmini Konaklama İşletmelerinde Bir Uygulama”. Illetişim Kuram ve Araştırma Dergisi 2011:163-184

Grubor A., Kovač Ž., Ružica, M., Dražen. “C-2-C Market Relations And Word Of Mouth”. Economic Annals, Volume Lx, No. 207 / October - December 2015

Halsted, C. H. (2003). “Dietary supplements and functional foods: 2 sides of a coin?”. The American journal of clinical nutrition, 77(4), 1001- 1007.

Odabaşı Y., Gülfidan B. (2002), “Tüketici Davranışı”. 2. Baskı, Media Cat Kitapları,. Kapital Medya İstanbul

Sunay H., Balcı V. (2003 ) "Bazı Türk Televizyonlarının Yayınladı̆̆ı Reklamlarda Spor İmajının Kullanımı”. Spormetre Beden Eğitimi ve Spor Bilimleri Dergisi, I (2) 107-110

Yıldız, Y., Çetinöz, F., Kaplan, Y., \& Türkmen, M. (2007). “TV reklamlarında spor imajının kullanılması ve tüketici davranışları üzerine etkisi”. Spor Yönetimi ve Bilgi Teknolojileri Dergisi, 2(1), 5-13.

Yücesir İ., (2009). “Doping ve doping ile mücadele yöntemleri”. Klinik Gelişim, 22(1), 26-37.

\section{Extended abstract in English}

The need for access to information and how it is satisfied by the consumer has a great importance in marketing researchs. Today, WOM(word of mouth) marketing communication, which is one of the face-to-face communication types, is an information exchange method shaping the consumer's consumption decisions.

Nutritional supplements which occupies an important place in the sports products market are not only used by elite athletes, but also used by those engaged in recreational sports activities. As a subject of our research; the consumption of nutritional support products, WOM marketing communication has a great influence. While building their knowledge of these products, people who perform a sport care about the past experiences of others, want to have knowledge about the triedand-true product, and and make purchasing decisions based on the information that they have achieved.

Our study aims to understand effects of word of mouth communication on Europe side of Istanbul sport centers participants decision making process about nutritional supplements purchase. The participants of survey choosen randomly are between the range of 16-51 and their average of age is 28 . Totally 138 person were participated to study. Aydin makes validity and reliability test and survey form includes 30 questions and three parts. Five unit Likert scale is used. The data were tested by SPSS 20. Frequency, crosstab, t-test-anova analysis were used. 
Dal, S., Çavuşoğlu, S.B., Karaman, Ö. (2017). Ağızdan ağıza pazarlama iletişiminin, fitness merkezi kullanıcılarının besin destek ürünü satınalma karar sürecine etkisi. International Journal of Social Sciences and Education Research, 3(2), 456-466.

We observed that the vast majority of fitness center users receiving nutritional support are university graduated and when purchasing nutritional supplements, $\% 83$ of men and $\% 79$ of women are considering experience, information, and advices. The participants considering experience, information, and advices and they preferred $\% 34.8$ protein powder, $\% 10.9$ amino asit, $\%$ 8.7 le-carnitine or cla products.

Men participants are purchasing products via internet and they use respectively chat and forum websites, shopping websites and news websites. Women participants are purchasing products via internet and they use respectively chat and forum websites, video share websites and shopping websites.

While making purchase decision, participants of our study care, $\% 46.4$ of them expertness of source, $\% 29.7$ of them care consultants experience, $\% 15.2$ of them care consultants information. We observed that men considering experience, information and advice more than women at their nutrition supplement purchasing process. it can be said that the sources experience, information and expertness has a significant role at consumers purchasing decisions.

As a consequence; it has been observed that WOM marketing communication has a positive influence on the decision-making process of Istanbul sport centers participants using nutritional support products. 